\title{
Original
}

\section{Environmental Impact of Tributyltin-Resistant Marine Bacteria in the Indigenous Microbial Population of Tributyltin-Polluted Surface Sediments}

\author{
HARUO MIMURA ${ }^{1 *}$, MASAHIRO YAGI ${ }^{2}$, AND KAZUTOSHI YOSHIDA ${ }^{3}$ \\ ${ }^{1}$ Graduate School of Maritime Sciences, Kobe University, Kobe 658-0022, Japan \\ ${ }^{2}$ Department of Environmental Chemistry, Kobe Institute of Health, Kobe 650-0046, Japan \\ ${ }^{3}$ Hyogo Prefectural Institute of Technology, Kobe 654-0037, Japan \\ Received 4 August, 2015/Accepted 19 November, 2016
}

\begin{abstract}
We compared the TBT-resistant ability of resting cells prepared from isolates that formed colonies on nutrient agar plates containing $100 \mu \mathrm{M}$ tributyltin (TBT) chloride, such as Photobacterium sp. TKY1, Halomonas sp. TKY2, and Photobacterium sp. NGY1, with those from taxonomically similar type strains. Photobacterium sp. TKY1 showed the highest ability among those three isolates. The number of surviving Photobacterium sp. TKY1 cells was hardly decreased after $1 \mathrm{~h}$ of exposure to $100 \mu \mathrm{M} \mathrm{TBTCl}$, regardless of the number of resting cells in the range from $10^{9.4}$ to

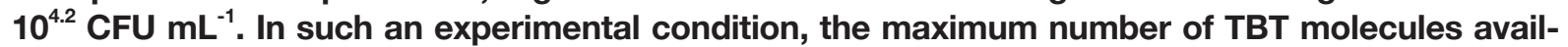
able to associate with a single cell was estimated to be approximately $6.0 \times 10^{11.8}$. Resting cells prepared from type strains Photobacterium ganghwense JCM $12487^{\top}$ and $P$. halotolerans LMG $22194^{\top}$, which have $16 \mathrm{~S}$ rDNA sequences highly homologous with those of Photobacterium sp. TKY1, showed sensitivity to TBT, indicating that TBT-resistant marine bacterial species are not closely related in spite of their taxonomic similarity. We also estimated the impact of TBT-resistant bacterial species to indigenous microbial populations of TBT-polluted surface sediments. The number of surviving TBT-sensitive Vibrio natriegens ATCC $14048^{\top}$ cells, $10^{6.2 \pm 0.3} \mathrm{CFU} \mathrm{mL}^{-1}$, was reduced to $10^{4.4 \pm 0.4} \mathrm{CFU} \mathrm{mL}{ }^{-1}$ when TBT-resistant Photobacterium sp. TKY1 cells, $10^{9.1 \pm 0.2} \mathrm{CFU} \mathrm{mL}^{-1}$, coexisted with $10^{9.4 \pm 0.2} \mathrm{CFU} \mathrm{\textrm {mL } ^ { - 1 }}$ of $V$. natriegens ATCC $14048^{\top}$ cells in the presence of $100 \mu \mathrm{M}$ TBTCl. These results indicate that the toxicity of TBT to TBT-sensitive marine bacterial populations might be enhanced when a TBT-resistant marine bacterial species inhabits TBT-polluted surface sediments.
\end{abstract}

Key words : TBT-resistant marine bacteria / Busy ports / TBT-polluted surface sediments / Survivability.

\section{INTRODUCTION}

The usage of organotin compounds had expanded worldwide because of their broad applications in industry and agriculture as catalysts, polyvinyl chloride stabilizers, biocides for fungi, bacteria, and insects, and wood preservatives (Hoch, 2001). In particular, tributyltin (TBT) oxide, TBT chloride (TBTCl), and triphenyltin (TPhT) chloride were used to prevent biofouling on ship hulls since the 1970s, resulting in extensive pollution by these organotin compounds in the marine envi-

*Corresponding author. Tel: +81-78-431-6344, Fax: +81-78431-6365, E-mail : hmimura(a)maritime.kobe-u.ac.jp ronment (Sudaryanto et al., 2002; Murai et al., 2005; Furdek et al., 2012). Pollution by organotin compounds has already spread to the Antarctic Ocean. In sediments close to the channels of Antarctica, high concentrations of organotin compounds, up to 2,290 $\mathrm{mg} \mathrm{Sn} \mathrm{kg}^{-1}$ sediment, were detected (Negri et al., 2004). Therefore, marine pollution by TBT originating from antifouling paints is still a great concern (Antizar-Ladislao, 2008).

Bioaccumulation of organotin compounds causes chronic toxicity in living things (Ebdon et al., 1989; Ueno et al., 2004; Harino et al., 2007). The compounds also act as endocrine disrupters (Oberdörster et al., 1998; Horiguchi et al., 2002). In addition to their toxicity, mutagenic effects on the Bacillus subtilis $\mathrm{Rec}^{+}$or Rec 
strain (Hamasaki et al., 1992), Salmonella Typhimurium (Hamasaki et al., 1993) and the marine worm (Hagger et al., 2002) have been confirmed. The International Maritime Organization (IMO) has since prohibited the use of such organotin compounds as antifouling biocides through the International Convention on the Control of Harmful Anti-fouling Systems on Ships (IMO, 2008). While the use of TBT must be avoided, Lewis et al. (2004) emphasized the importance of preventing biofouling on ship hulls to prevent the invasion of nonindigenous marine organisms.

Tributyltin-resistant, or TBT degrading, bacteria have been isolated from marine environments. A TBT-resistant marine Alteromonas sp., growing in the presence of $125 \mu \mathrm{M} \mathrm{TBTCl}$, was isolated from coastal seawater (Fukagawa et al., 1992). A protein from the cloned genes deduced to be responsible for TBT resistance was found to be related to $\mathrm{Na}^{+} / \mathrm{H}^{+}$antiporters and various $\mathrm{Ca}^{2+}$ transporters (Fukagawa and Suzuki, 1993). A multidrug efflux pump was shown to be essential to TBT resistance in Pseudomonas stutzeri (Jude et al., 2004). Adsorption of TBT molecules is an important function of cell walls for Pseudoalteromonas sp. to prevent the inflow of molecules into the cytoplasm (Kubota et al., 2004; Mimura et al., 2008a; Mimura et al., 2008b). Recently, a TBT-degrading Aeromonas veronii, which uses TBT as a carbon source, was isolated from an estuarine environment (Cruz et al., 2007). It seems that the strain could be applied to repair to TBT-polluted sediments.

Organotin compounds are stable and have existed mainly in sediments, rather than in seawater, for prolonged periods (Dowson et al., 1993; Hashimoto, 1998; Hoch, 2001; Saeki et al., 2007; Antizar-Ladislao, 2008), indicating that the frequency of mutations related to TBT resistance might occur in indigenous marine bacteria in sediments (Wuertz et al., 1991; Suzuki et al., 1992; Chen and White, 2004) and that sublethal concentrations of TBT in such sediments give considerable damage to the bacterial ecosystems. Therefore, in this study, we compared survivability of an isolate, from sediments of busy ports such as Tokyo Bay and Ise Bay, with taxonomically similar type strains in the presence of TBT to know whether or not the tolerance is in the genus level. In addition, the impact of an indigenous TBT-resistant bacterium was estimated for microbial populations in TBT-polluted surface sediments.

\section{MATERIALS AND METHODS}

\section{Isolation of TBT-resistant marine bacteria}

Sampling of surface sediments was carried out in 2008 using a Van Dorn water sampler (5026, Rigosha
Co., Ltd., Tokyo, Japan) on board a training ship when anchored at the quarantine anchorages in Tokyo Bay (35.58 N, 139.85 E) and Ise Bay (34.97 N, 136.78 E), Japan. The depth of the water at the sampling sites was 14 to $15 \mathrm{~m}$, and the seawater temperature was 20 to $24^{\circ} \mathrm{C}$. Each surface sediment sample was poured into an autoclaved bottle with a screw cap. The samples thus obtained were stored on board up to 7 days at $4^{\circ} \mathrm{C}$. When the ship called at a port, samples kept in a cool box were sent to the laboratory.

One hundred $\mu \mathrm{L}$ of the sample was taken after vigorous shaking and spread onto a nutrient agar plate containing $5.0 \mathrm{~g}$ Bacto Peptone (Difco, Sparks, MD, USA), $1.0 \mathrm{~g}$ yeast extract (Difco, Sparks, MD, USA), $15 \mathrm{~g}$ agar in seawater (liter ${ }^{-1}$ ), and $100 \mu \mathrm{M}$ TBTCl as a final concentration. TBTCl was added to the medium after it was autoclaved. After the sample was spread onto an agar plate, it was incubated for 5 days at $25^{\circ} \mathrm{C}$, and a single colony formed on the plate was picked up with an autoclaved toothpick and streaked onto a new agar plate. Three TBT-resistant species thus obtained were used for identification and experiments.

\section{Identification of isolates}

Identification of the isolates was carried out commercially on the basis of partial 16S rDNA sequences. Briefly, a partial 16S rDNA fragment from the V1 to V3 region (about $500 \mathrm{bp}$ ) was amplified by PCR and sequenced with a MicroSeq ${ }^{\circledR} 500$ 16S rDNA kit (Applied Biosystems, Foster City, CA, USA). The sequencing data obtained were used for homology analysis using the database, Apron DB-BA Version 4.0 (TechnoSuruga Laboratory, Shizuoka, Japan). A phylogenetic tree was constructed by the neighbor-joining method (Saitou and Nei, 1987). Partial 16S rDNA sequences of Photobacterium sp. TKY1, Halomonas sp. TKY2, and Photobacterium sp. NGY1 were deposited in the DDBJ/GenBank/EMBL under the accession numbers of AB501122, AB501213, and AB511030, respectively.

\section{Enumeration of colony-forming cells after expo- sure to TBT}

Resting cells prepared from the isolate and two type strains most like it based on partial rDNA sequences were examined. Cells grown until the early stationary phase of growth were harvested by centrifugation (10,000 $\times g, 5 \mathrm{~min})$, washed twice with $50 \mathrm{mM}$ potassium-phosphate (K-Pi) buffer, $\mathrm{pH} 7.8$, containing $0.5 \mathrm{M}$ $\mathrm{NaCl}$, and resuspended in the same volume with the buffer $(1 \mathrm{~mL})$. We varied the initial number of resting cells $\left(\mathrm{mL}^{-1}\right)$ by serial dilution prior to the addition of TBTCl at a final concentration of $100 \mu \mathrm{M}$. After exposure to TBT for $1 \mathrm{~h}$, the cell suspension was diluted 
serially and spread onto a nutrient agar plate. After incubation for 4 days at $25^{\circ} \mathrm{C}$, colonies on the plate were enumerated.

We used a nutrient agar plate containing $5.0 \mathrm{~g}$ Bacto Peptone, $1.0 \mathrm{~g}$ yeast extract, $20 \mathrm{~g}$ sucrose, $0.04 \mathrm{~g}$ bromothymol blue, and $15 \mathrm{~g}$ agar in seawater $\left(\right.$ liter $\left.^{-1}\right)$ to enumerate each number of surviving cells such as $V$. natriegens ATCC $14048^{\top}$ as well as Photobacterium sp. TKY1 in their mixture in the presence and absence of $100 \mu \mathrm{M}$ TBTCl. We could distinguish colonies of $V$. natriegens ATCC $14048^{\top}$ from those of Photobacterium $\mathrm{sp}$. TKY1 because the former strain grew faster than the latter on the agar plate, and sucrose metabolites from $V$. natriegens ATCC $14048^{\top}$ acidified the medium $\mathrm{pH}$, with changes in the color of a colony to yelloworange.

\section{Measurement of cell-associated TBT}

Photobacterium sp. TKY1 cells were pre-incubated for 1.5 days at $25^{\circ} \mathrm{C}$ in the medium containing $5.0 \mathrm{~g}$ Bacto Peptone, $1.0 \mathrm{~g}$ yeast extract, and $29.2 \mathrm{~g} \mathrm{NaCl}$ in 50 mM K-Pi buffer (liter ${ }^{-1}$ ). After pre-incubated cells (30 $\mu \mathrm{L}$ ) were inoculated into the medium $(30 \mathrm{~mL})$, incubation was carried out for 1.5 days at $25^{\circ} \mathrm{C}$. Cells in the broth $(10 \mathrm{~mL})$ were harvested with centrifugation (5 min, 10,000 × g), washed twice with $50 \mathrm{mM} \mathrm{K-Pi} \mathrm{buffer,}$ $\mathrm{pH} 7.5$, containing $0.5 \mathrm{M} \mathrm{NaCl}$, and resuspended in the buffer $(10 \mathrm{~mL})$. Cells were also grown in the presence of $100 \mu \mathrm{M}$ TBTCl for 4 days at $25^{\circ} \mathrm{C}$.

As for the cells grown in the absence of TBTCl, 30 $\mathrm{mM}$ TBTCl dissolved in ethanol was added to the cell suspension in a glass test tube (diameter: $20 \mathrm{~mm}$; length: 180 mm, AGC Techno Glass Co., Ltd., Shizuoka, Japan) to give a final concentration of $100 \mu \mathrm{M}$. Then the glass test tube was vigorously shaken for $1 \mathrm{~min}$ and left for $1 \mathrm{~h}$. After centrifugation, supernatant was pipetted out and added to a different glass tube with a screw cap. The centrifuge tube was briefly centrifuged again, and then remaining supernatant at the bottom of the tube was removed carefully by pipetting. A cell pellet thus obtained was resuspended in $50 \mathrm{mM} \mathrm{K}$-Pi buffer, $\mathrm{pH}$ 7.5, and the volume was adjusted up to $10 \mathrm{~mL}$ with the buffer. As for cells grown in the presence of $100 \mu \mathrm{M}$ TBTCI, the samples prepared from the supernatant and the cell pellet were obtained using the same procedure described above. The sample was also obtained from the growth medium alone after adding $100 \mu \mathrm{M}$ TBTCl as a final concentration. The glass test tube containing growth medium ( $10 \mathrm{~mL}$ ) and $100 \mu \mathrm{M}$ TBTCl was vigorously shaken for $1 \mathrm{~min}$, and then an aliquot of the mixture $(1 \mathrm{~mL})$ was pipetted out and kept in a glass tube with a screw cap.

The samples of the supernatant as well as the growth medium alone, in which TBTCl was added to give a final concentration of $100 \mu \mathrm{M}$, were measured with a HPLC (Waters 2695, Milford, MA, USA) equipped with an electrospray tandem mass spectrometer (Waters Quattro Micro, Milford, MA, USA) (HPLC/MS/MS) without pretreatment. Pretreatment was carried out to measure cell-associated TBT. Cell suspensions (100 $\mu \mathrm{L})$ were pipetted out and added to acetonitrile $(9 \mathrm{~mL})$. After sonication for $5 \mathrm{~min}$, the sample was centrifuged. The supernatant thus obtained was adjusted to $10 \mathrm{~mL}$ with acetonitrile.

The mixture of $0.1 \%$ formic acid $(60 \mathrm{~mL})$ with acetonitrile $(40 \mathrm{~mL}$ ) was used as the moving phase of the liquid chromatographic column $(2.0 \mathrm{~mm}$ inner diameter x $150 \mathrm{~mm}$ length), in which TSKgel Octadecyl-2PW (5- $\mu$ m mean particle size) was filled. The mixture's flow rate was $0.2 \mathrm{~mL} / \mathrm{min}$. The injection volume of the sample was adjusted to $10 \mu \mathrm{L}$. A stable isotope, TBT-d27Cl, was used as a surrogate, in which hydrogen was replaced with deuterium. The method of selected reaction monitoring was employed to quantify TBT in the sample.

\section{Observation of morphological changes in isolates by scanning electron microscopy}

Resting cells suspended in $50 \mathrm{mM} \mathrm{K}$-Pi buffer, $\mathrm{pH}$ 7.5 , that contained $0.5 \mathrm{M} \mathrm{NaCl}$ were prepared from Photobacterium sp. TKY1 cells grown in the medium described previously for 4 days at $25^{\circ} \mathrm{C}$ in the absence or presence of $100 \mu \mathrm{M}$ TBTCl. Resting cells were also prepared from cells grown in the absence of TBTCl for 1.5 days at $25^{\circ} \mathrm{C}$, and exposed to TBTCl at a final concentration of $100 \mu \mathrm{M}$ for $1 \mathrm{~h}$.

Resting cells prepared from $V$. natriegens ATCC $14048^{\top}$ reaching the early stationary phase of growth were mixed with those obtained from Photobacterium sp. TKY1 cells, and then the cell mixture was exposed to TBT at a final concentration of $100 \mu \mathrm{M}$ for $1 \mathrm{~h}$.

Cells examined were fixed with $1 \%$ (vol/vol) glutaraldehyde, as a final concentration, for $1 \mathrm{~h}$ at $4^{\circ} \mathrm{C}$, dehydrated once for $1 \mathrm{~h}$ in 50, 70, 90, 95, and 100\% ethanol, and suspended in 100\% $t$-butyl alcohol. After being freeze-dried, they were pasted on a carbon tape and coated with $\mathrm{Pd}-\mathrm{Pb}$ particles under vacuum. Samples thus obtained were observed with a scanning electron microscope (XL30 CP, FEl Company, Eindhoven, the Netherlands).

\section{Purchase of chemicals}

Tributyltin chloride, of greater than 95\% purity, was purchased from Wako Pure Chemical Industries, Ltd. (Wako, Japan). Other chemicals used were of high grade. 


\section{RESULTS AND DISCUSSION}

\section{Phylogenetic similarity of each isolate with type strains}

The homologous percentage of the type strain to each isolate was more than $98.5 \%$, based on partial $16 S$ rDNA sequences, except for $P$. halotolerans LMG $22194^{\top}(94.2 \%)$ and $P$. damsela ATCC $33539^{\top}$ (95.2\%) (Table 1). So far, Photobacterium sp. TKY1, Halomonas sp. TKY2, and Photobacterium sp. NGY1 were very close to $P$. ganghwense JCM $12487^{\top}, H$. venusta DSM $4743^{\top}$, and P. rosenbergii LMG $22228^{\top}$, respectively.

\section{Tributyltin-resistant ability of resting cells}

We examined changes in the TBT-resistant ability of each isolate as well as those of its type strains to a constant number of TBT molecules, $6.0 \times 10^{19} \mathrm{~mL}^{-1}$ when the number of resting cells varied up to $10^{9} \mathrm{CFU} \mathrm{\textrm {mL } ^ { - 1 }}$ (Fig.1). The number of cell-associated TBT molecules with a single cell increases in response to the reduction of the number of resting cells in the experiment. As a result, the number of resting cells of Photobacterium sp. TKY1 was hardly reduced even when the initial number of resting cells varied from $10^{9.4}$ to $10^{4.2} \mathrm{CFU}$ $\mathrm{mL}^{-1}$, at which the number of surviving cells was $10^{3.8}$ CFU mL ${ }^{-1}$ (Fig.1A). In such experimental conditions, the number of cell-associated TBT molecules increased by

TABLE 1. List of two type strains with high similarities to the $16 \mathrm{~S}$ rDNA sequences of each isolate

\begin{tabular}{|c|c|c|c|}
\hline Strain isolated & Type strains $^{a}$ & Origin of the type strain & References \\
\hline \multirow{2}{*}{$\begin{array}{l}\text { Photobacterium sp. } \\
\text { TKY1 }\end{array}$} & Photobacterium ganghwense JCM $12487^{\top}(99.4 \%)^{b}$ & Seawater & Park et al. (2006) \\
\hline & Photobacterium halotolerans LMG $22194^{\top}$ (94.2\%) & Saline lake & Rivas et al. (2006) \\
\hline \multirow{2}{*}{$\begin{array}{l}\text { Halomonas sp. } \\
\text { TKY2 }\end{array}$} & Halomonas venusta DSM $4743^{\top}$ (99.6\%) & Seawater & Baumann et al. (1972) \\
\hline & Halomonas alkaliphila DSM 16354 (99.6\%) & Salt pool & Romano et al. (2006) \\
\hline \multirow{2}{*}{$\begin{array}{l}\text { Photobacterium sp. } \\
\text { NGY1 }\end{array}$} & Photobacterium rosenbergii LMG $22228^{\top}$ (98.5\%) & Bleached coral & Thompson et al. (2005) \\
\hline & Photobacterium damsela ATCC 33539 (95.2\%) & Damselfish skin ulcers & Smith et al. (1991) \\
\hline
\end{tabular}

${ }^{a}$ We selected two kinds of type strains, which showed high first and secondary similarities to the 16S rDNA sequences of each isolate, based on the database of Apron DB-BA Version 4.0 (TechnoSuruga Laboratory Co., Ltd.).

${ }^{\mathrm{b}}$ The homologous percentage between the isolate and each type strain is shown in parentheses. The type strain listed in the upper line made a cluster with the isolate on the phylogenetic tree.
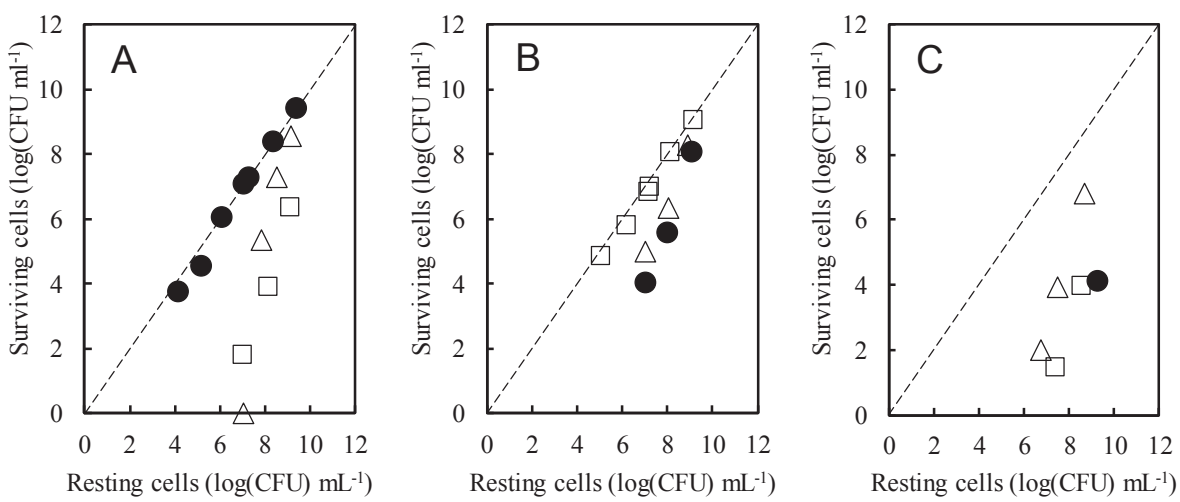

FIG. 1. Changes in the survivability of the isolate and the taxonomically similar type strains in relation to the given numbers of resting cells exposed to TBT

Surviving cells were counted by the colony-counting method after exposure to $100 \mu \mathrm{M}$ of TBT for $1 \mathrm{~h}$. The number of cell-associated TBT molecules varied with the number of resting cells exposed to TBT. Changes in the number of surviving cells of Photobacterium sp. TKY1 (O), P. ganghwense JCM $12487^{\top}(\triangle)$, and $P$. halotolerans LMG 22194 $(\square)$ are shown in relation to given numbers of resting cells (Fig.1A). The results obtained from Halomonas sp. TKY2 $(\mathbf{O}), H$. venusta DSM $4743^{\top}(\triangle)$, and $H$. alkaliphila DSM $16354^{\top}(\square)$ cells are shown in Fig.1B. For Photobacterium sp. NGY1 (O), P. rosenbergii LMG $22228^{\top}(\triangle)$, and P. damsela ATCC $33539^{\top}(\square)$, the number of surviving cells is shown in Fig. $1 \mathrm{C}$. The dotted line in each figure means perfect survivability, regardless of the initial number of resting cells. 
5-orders of magnitude, indicating that the isolate was highly resistant to TBT. When resting cells of $10^{9.2} \mathrm{CFU}$ $\mathrm{mL}^{-1}$ were exposed to TBT for $1 \mathrm{~h}$, surviving cells of $P$. ganghwense JCM $12487^{\top}$ were reduced to $10^{8.5} \mathrm{CFU}$ $\mathrm{mL}^{-1}$. Survivability, however, drastically reduced from $10^{5.3} \mathrm{CFU} \mathrm{\textrm {mL } ^ { - 1 }}$ to zero when the number of resting cells

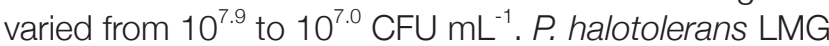
$22194^{\top}$ also showed a result similar to that of $P$. ganghwense $\mathrm{JCM} 12487^{\top}$. The number of surviving cells was $10^{6.3} \mathrm{CFU} \mathrm{mL}{ }^{-1}$ when resting cells of $10^{9.2} \mathrm{CFU} \mathrm{mL}^{-1}$ were exposed to such a number of TBT molecules $\left(\mathrm{mL}^{-1}\right)$. The number of surviving cells was reduced to $10^{1.8} \mathrm{CFU}$ $\mathrm{mL}^{-1}$ when the resting cells of $10^{7.0} \mathrm{CFU} \mathrm{mL}{ }^{-1}$ were exposed to the same concentration of TBT.

The sensitivity of Halomonas sp. TKY2 and $\mathrm{H}$. venusta DSM $4743^{\top}$ to TBT were enhanced in relation to the reduction of the initial number of resting cells (Fig.1B). When the resting cells of $10^{7.0} \mathrm{CFU} \mathrm{mL}^{-1}$ were examined, the surviving cells of Halomonas sp. TKY2 and $H$. venusta DSM $4743^{\top}$ were reduced by 3 - and 2 -orders of magnitude, respectively, whereas the reduction of surviving cells prepared from each strain was repressed by 0.6 -order of magnitude to the initial number of resting cells, $10^{8.9} \mathrm{CFU} \mathrm{mL}{ }^{-1}$. For Halomonas sp. TKY2 and $H$. venusta DSM $4743^{\top}$ cells, no surviving cells were observed when the number of resting cells was less

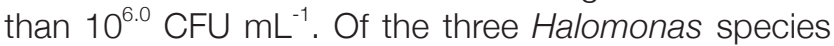
examined thus far, $H$. alkaliphila DSM $16354^{\top}$ cells showed the highest survivability. The number of surviving cells hardly decreased when the number of resting cells varied from $10^{9.2}$ to $10^{5.1} \mathrm{CFU} \mathrm{mL}{ }^{-1}$. The reduction of surviving cells was on 0.3-order of magnitude, even when the resting cells, such as $10^{5.1} \mathrm{CFU} \mathrm{mL}^{-1}$, were exposed to TBT. H. alkaliphila DSM $16354^{\top}$ was isolated from the water of a salt pool in Italy (Romano et al., 2006). It might be plausible to think that the highly resistant ability is not caused by prolonged exposure to sublethal TBT concentrations, but fundamentally possessed by the strain. Further study of the resistance of $H$. alkaliphila DSM $16354^{\top}$ to TBT is necessary.

Changes in the survivability of a given number of resting cells of Photobacterium sp. NGY1, $P$. rosenbergii LMG $22228^{\top}$, and $P$. damsela ATCC $33539^{\top}$ were examined (Fig.1C). The number of surviving cells of Photobacterium sp. NGY1 drastically decreased to $10^{4.2}$ CFU mL ${ }^{-1}$ when the initial number of $10^{9.3} \mathrm{CFU} \mathrm{mL}^{-1}$ was exposed to TBT for 1 h. P. rosenbergii LMG $22228^{\top}$ showed relatively higher survivability as compared to Photobacterium sp. NGY1. The numbers of surviving

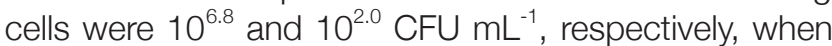
resting cells of $10^{8.7}$ and $10^{6.8} \mathrm{CFU} \mathrm{\textrm {mL } ^ { - 1 }}$ were exposed to TBT for $1 \mathrm{~h}$. Resting cells of $P$. damsela ATCC $33539^{\top}$ showed similar sensitivity to $P$. rosenbergii LMG $22228^{\top}$.

The isolates, Photobacterium sp. TKY1, Halomonas sp. TKY2, and Photobacterium sp. NGY1, formed colonies on the nutrient agar plate containing $100 \mu \mathrm{M}$ TBT within 5 days of incubation at $25^{\circ} \mathrm{C}$ (see MATERIALS AND METHODS). The sensitivity to TBT of Halomonas sp. TKY2 and Photobacterium sp. NGY1, however, was enhanced with the reduction of the initial number of resting cells in the presence of $100 \mu \mathrm{M}$ TBT, indicating that some kinds of amino acids might essential for the survival of the strains, i.e., syntheses of stress proteins for coping with the toxicity of TBT (Nováková et al., 2009). Resting cells prepared from the isolate, Photobacterium sp. TKY1, and the type strain, H. alkaliphila DSM $16354^{\top}$, showed high survivability to TBT, indicating that they might have constitutively expressed transporters such as the multidrug efflux pump, TbtABM, in the membrane found in P. stutzeri (Jude et al., 2004).

\section{Capacity of adsorption of TBT molecules as an indicator of tolerance to TBT}

Cell-associated TBT molecules were measured with a HPLC/MS/MS. As shown in Table 2, growing Photobacterium sp. TKY1 cells as well as resting cells,

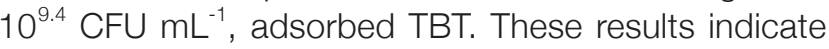
that the isolate could grow in the nutrient liquid medium to cope with the adsorption of TBT molecules by the growing cells. The cell wall of the isolate might play an important role to prevent the interaction of TBT molecules with the cell membrane. The concentration of TBT recovered from the medium alone was found to be 65.0 $\mathrm{nmol} \mathrm{mL}^{-1}$. The concentration was lower than the adjusted concentration of $100 \mathrm{nmol} \mathrm{mL}^{-1}$. It seemed that some of the TBT molecules were not recovered due to their adhesion onto the inside of the glass test tube and chips used for pipetting.

We have pointed out previously that the cell wall of a marine Pseudoalteromonas sp. plays an important role in preventing the inflow of TBT molecules into the cytoplasm across the membrane (Kubota et al., 2004; Mimura et al., 2008a; Mimura et al., 2008b). The isolate, Photobacterium sp. TKY1, could adsorb TBT molecules, approximately $3.5 \times 10^{6.6}$ (a single cell ${ }^{-1}$ ), when resting cells were examined. The order of the value was consistent with that obtained from TBTresistant marine Pseudoalteromonas sp. cells examined in the presence of $100 \mu \mathrm{M} \mathrm{TBTCl}$ (Mimura et al., 2008b). Those results indicate the importance of the cell wall's function and capacity to adsorb TBT molecules on the surface in relation to the resistance of the species to TBT toxicity.

\section{Estimation of the impact of a TBT-resistant bacte- rium on the indigenous microbial population}

We estimated the impact of a TBT-resistant marine bacterium on an indigenous microbial population in 
TABLE 2. Adsorption of TBT molecules by Photobacterium sp. TKY1 cells

\begin{tabular}{|c|c|c|}
\hline & 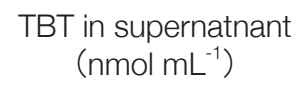 & $\begin{array}{c}\text { Cell-associated } \text { TBT }^{d} \\
\left(\mathrm{nmol}(\mathrm{mg} \text { cell protein })^{-1}\right)\end{array}$ \\
\hline Cells grown in the presence of $\mathrm{TBTCl}^{\mathrm{a}}$ & 7.2 & 187.4 \\
\hline Resting cells ${ }^{\mathrm{b}}$ & 7.6 & 142.5 \\
\hline Medium alone $^{c}$ & 65.0 & - \\
\hline \multicolumn{3}{|c|}{$\begin{array}{l}{ }^{a} \text { Cells were grown in the presence of } 100 \mu \mathrm{M} \text { TBTCl for } 4 \text { days at } 25^{\circ} \mathrm{C} \text {. After their harvest, TBT in the } \\
\text { supernatnat as well as the cell pellet were measured. } \\
{ }^{\mathrm{b}} \text { Resting cells were prepared from the cells grown in the absence of TBTCl for } 1.5 \text { days at } 25^{\circ} \mathrm{C} \text {. After } \\
\text { being harvested and washed twice, cells were suspended in } 50 \mathrm{mM} \mathrm{K} \text {-Pi buffer, } \mathrm{pH} 7.5 \text {, containing } 0.5 \\
\mathrm{M} \mathrm{NaCl} \text {. TBT concentrations in supernatant and cell pellets were measured after the addition of } 100 \\
\mu \mathrm{M} \mathrm{TBTCl,} \mathrm{as} \mathrm{the} \mathrm{final} \mathrm{concentration,} \mathrm{for} 1 \mathrm{~h} \text {. } \\
{ }^{\mathrm{c}} \text { TBTCl, as the final concentration of } 100 \mu \mathrm{M} \text {, was added into the medium. After vigorous shaking, TBT } \\
\text { in the sample was measured. } \\
{ }^{\mathrm{d}} \text { Cell proteins of resting cells grown in the absence or presence of TBTCl were } 0.29 \mathrm{mg} \mathrm{mL}^{-1} \text { and } 0.42 \\
\mathrm{mg} \mathrm{mL}^{-1} \text {, respectively. }\end{array}$} \\
\hline
\end{tabular}

TABLE 3. Changes in survivability of TBT-sensitive Vibrio natriegens ATCC $14048^{\top}$ cells when TBT-resistant Photobacterium sp. TKY1 cells coexist in the presence of TBTCl

\begin{tabular}{|c|c|c|}
\hline \multirow{2}{*}{$\begin{array}{l}\text { Strains and each number of resting cells } \\
\left(\mathrm{CFU} \mathrm{mL} \mathrm{mL}^{-1}\right)\end{array}$} & \multicolumn{2}{|c|}{ Surviving cells in the presence of TBTCI $(100 \mu \mathrm{M})^{a}$} \\
\hline & 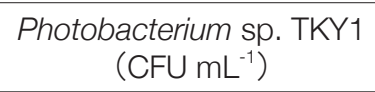 & 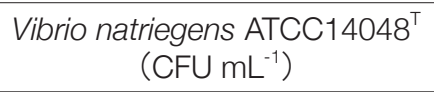 \\
\hline $\begin{array}{l}\text { Photobacterium sp. TKY1 }\left(10^{9.1 \pm 0.2}\right) \\
\text { and Vibrio natriegens ATCC } 14048^{\top}\left(10^{9.4 \pm 0.2}\right)^{\mathrm{b}}\end{array}$ & $10^{9.1 \pm 0.2}$ & $10^{4.4 \pm 0.4}$ \\
\hline Vibrio natriegens ATCC $14048^{\top}$ alone $\left(10^{9.4 \pm 0.2}\right)$ & - & $10^{6.2 \pm 0.3}$ \\
\hline
\end{tabular}

surface sediments polluted with a sublethal level of TBT (Table 3). When TBT-sensitive $V$. natriegens ATCC

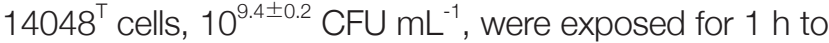
$100 \mu \mathrm{M}$ TBTCl, as a final concentration, the number of surviving cells was reduced to $10^{6.2 \pm 0.3} \mathrm{CFU} \mathrm{mL}{ }^{-1}$. When resting cells of $V$. natriegens ATCC $14048^{\top}$ were mixed with those of TBT-resistant Photobacterium sp. TKY1, the number of surviving cells of $V$. natriegens ATCC $14048^{\top}$ was found to be $10^{4.4 \pm 0.4} \mathrm{CFU} \mathrm{mL}{ }^{-1}$, the value of which decreased 2-orders of magnitude as compared with that when $V$. natriegens ATCC $14048^{\top}$ was examined alone. This result indicates that a coexistent TBTresistant marine bacterium stimulates TBT toxicity in TBT-sensitive microbial populations in surface sediments polluted with sublethal TBT concentrations. In order to maintain the microbial ecosystem, TBT contamination should be prevented, especially in the surface sediments of busy ports.

Morphological observation of Photobacterium sp. TKY1 and V. natriegens ATCC $14048^{\top}$ cells in the presence of TBT
Obvious morphological changes were not observed when Photobacterium sp. TKY1 cells were grown in the presence of $100 \mu \mathrm{M}$ TBTCl (Fig.2B) as well as after the addition of TBTCl to the resting cells (Fig.2D). Morphological changes of TBT-sensitive $V$. natriegens ATCC $14048^{\top}$ cells mixed with those of Photobacterium sp. TKY1 were observed in the presence of TBTCI (Fig. $2 \mathrm{~F}$ ). After exposure to TBT, ruptured or wrinkled $V$. natriegens ATCC $14048^{\top}$ cells were observed, while Photobacterium sp. TKY1 cells in the mixture retained their normal cell morphology. Since the cells were suspended in the presence of $0.5 \mathrm{M} \mathrm{NaCl}$, such changes in morphology seem to be closely related to the disruption of osmoregulation by the cation transport across the membrane (Fukagawa and Suzuki, 1993).

\section{ACKNOWLEDGMENTS}

We thank Dr. Takashi Miwa (of the National Institute for Sea Training at that time) for taking samples on board. This work was supported by a Grant-in-Aid for Scientific Research (C), JSPS.KAKENHI (21560830). 

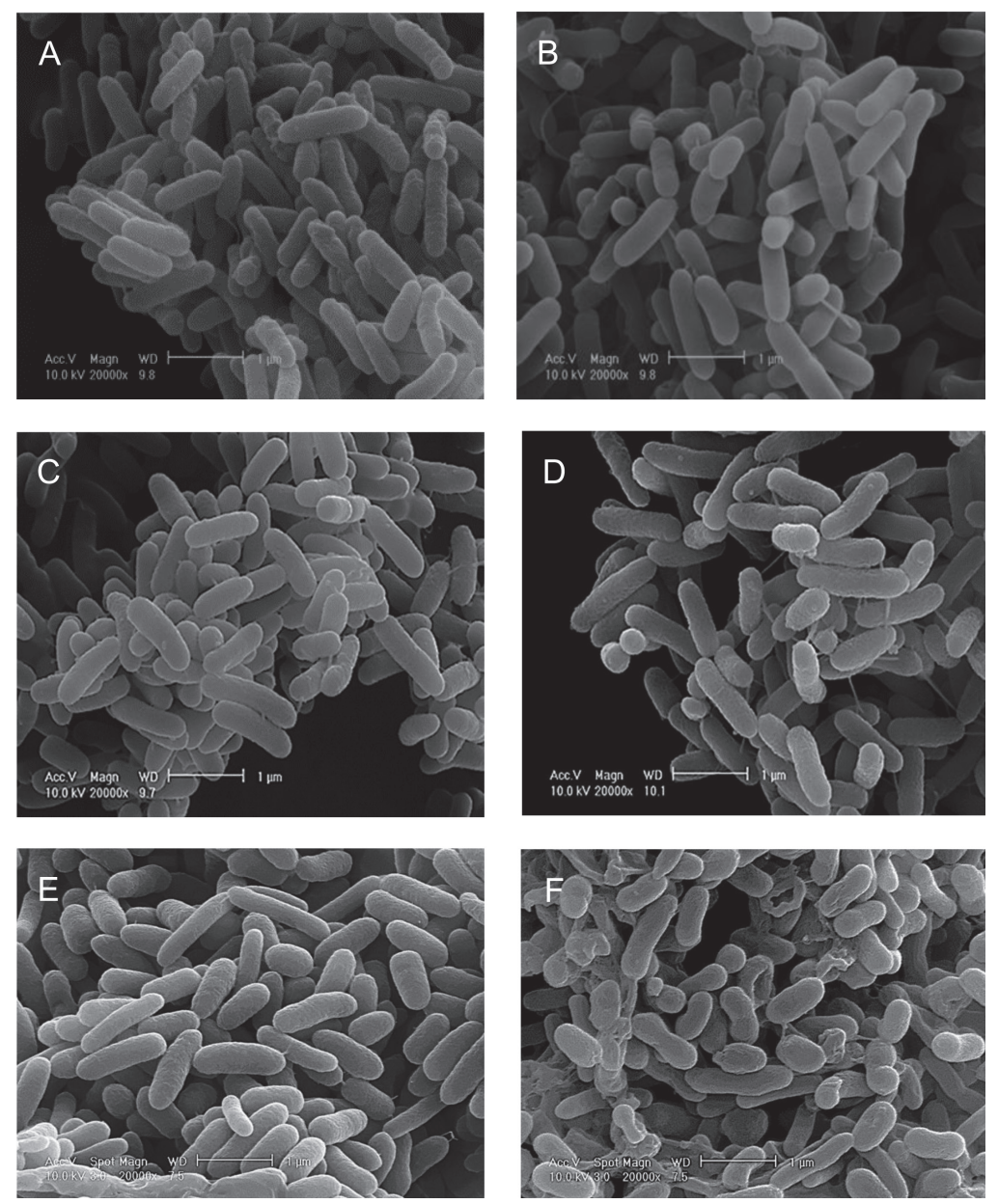

FIG. 2. Morphological changes of the isolate, Photobacterium sp. TKY1, Vibrio natriegens ATCC $14048^{\top}$, and their mixture in the presence of TBTCl with a scanning electron microscope

Morphological changes were observed with a scanning electron microscope with the following experimental conditions: Photobacterium sp. TKY1 cells were grown in the absence (Fig. 2A) or presence (Fig. 2B) of $100 \mu \mathrm{M}$ TBTCl as the final concentration; Resting cells (Fig. 2C) of Photobacterium sp. TKY1 were exposed to the same concentration of TBTCl for $1 \mathrm{~h}$ (Fig. 2D); A mixture of resting cells of Photobacterium sp. TKY1 and those of $V$. natriegens ATCC14048 ${ }^{\top}$ (Fig. 2E) was exposed to the same concentration of TBTCl as described above for $1 \mathrm{~h}$ (Fig. 2F).

\section{REFERENCES}

Antizar-Ladislao, B. (2008) Environmental levels, toxicity and human exposure to tributyltin (TBT)-contaminated marine environment. A review. Environ. Int., 34, 292-308.

Baumann, L., Baumann, P., Mandel, M., and Allen, R. D. (1972) Taxonomy of aerobic marine eubacteria. J. Bacteriol., 110, 402-429.

Chen, G., and White, P. A. (2004) The mutagenic hazards of aquatic sediments: a review. Mutat. Res., 567, 151-225.

Cruz, A., Caetano, T., Suzuki, S., and Mendo, S. (2007) Aeromonas veronii, a tributyltin (TBT)-degrading bacterium isolated from an estuarine environment, Ria de Aveiro in Portugal. Mar. Environ. Res., 64, 639-650.
Dowson, P. H., Bubb, J. M., and Lester, J. N. (1993) A study of the partitioning and sorptive behavior of butyltins in the aquatic environment. Appl. Organomet. Chem., 7, 623633.

Ebdon, L., Evans, K., and Hill, S. (1989) The accumulation of organotins in adult and seed oysters from selected estuaries prior to the introduction of $U$. K. regulations governing the use of tributyltin-based antifouling paints. Sci. Total Environ., 83, 63-84.

Fukagawa, T., Suzuki, S., Fukunaga, K., Suzuki, T., and Takama, K. (1992) Isolation and characterization of tributyltin chloride-resistant marine Vibrio. FEMS Microbiol. Lett., 93, 83-86.

Fukagawa, T., and Suzuki, S. (1993) Cloning of gene respon- 
sible for tributyltin chloride (TBTCl) resistance in TBTClresistant marine bacterium, Alteromonas sp. M-1. Biochem. Biophys. Res. Commun., 194, 733-740.

Furdek, M., Vahčič, M., Ščančar, J., Milačič, R., Kniewald, G., and Mikac, N. (2012) Organotin compounds in seawater and Mytilus galloprovincialis mussels along the Croatian Adriatic Coast. Mar. Pollut. Bull., 64, 189-199.

Hagger, J. A., Fisher, A. S., Hill, S. J., Depledge M. H., and Jha, A. N. (2002) Genotoxic, cytotoxic and ontogenetic effects of tir-n-butyltin on the marine worm, Platynereis dumerilii (Polychaeta: Nereidae). Aquat. Toxicol., 57, 243255.

Hamasaki, T., Sato, T., Nagase, H., and Kito, H. (1992) The genotoxicity of organotin compounds in SOS chromotest and rec-assay. Mutat. Res., 280, 195-203.

Hamasaki, T., Sato, T., Nagase, H., and Kito, H. (1993) The mutagenicity of organotin compounds as environmental pollutants. Mutat. Res., 300, 265-271.

Harino, H., Ohji, M., Wattayakorn, G., Adulyanukosol, K., Arai, T., and Miyazaki, N., 2007. Accumulation of organotin compounds in tissues and organs of stranded whales along the coasts of Thailand. Arch. Environ. Contam. Toxicol., 53, 119-125.

Hashimoto, S., Watanabe, M., Noda, Y., Hayashi, T., Kurita, Y., Takasu, Y., and Otsuki, A., 1998. Concentration and distribution of butyltin compounds in a heavy tanker route in the Strait of Malacca and in Tokyo Bay. Mar. Environ. Res., 45, 169-177.

Hoch, M. (2001) Organotin compounds in the environment -an overview. Appl. Geochem., 16, 719-743.

Horiguchi, T., Kojima, M., Kaya, M., Matsuo, T., Shiraishi, H., Morita, M., and Adachi, Y. (2002) Tributyltin and triphenyltin induce spermatogenesis in ovary of female abalone, Haliotis gigantea. Mar. Environ. Res., 54, 679-684.

International Maritime Organization (2008) International convention on the control of harmful anti-fouling systems on ships. Available in http://www.imo.org/OurWork/ Environment/Anti-foulingSystems/Pages/Default.aspx. Accessed 27 July 2015.

Jude, F., Arpin, C., Brachet-Castang, C., Capdepuy, M., Caumette, P., and Quentin, C. (2004) TbtABM, a multidrug efflux pump associated with tributyltin resistance in Pseudomonas stutzeri. FEMS Microbiol. Lett., 232, 7-14.

Kubota, N., Mimura, H., Yamauchi, T., and Kitamura, A. (2004) Accelerator analyses of tributyltin chloride associated with a tributyltin resistant marine microorganism. Mar. Pollut. Bull., 48, 800-805.

Lewis, P. N., Riddle, M. J., and Hewitt, C. L. (2004) Management of exogenous threats to Antarctica and the sub-Antarctic Islands: Balancing Risks from TBT and Non-Indigenous Marine Organisms. Mar. Pollut. Bull., 49, 999-1005.

Mimura, H., Sato, R., Furuyama, Y., Taniike, A., Yagi, M. Yoshida, K., and Kitamura, A. (2008a) Adsorption of tributyltin by tributyltin resistant marine Pseudoalteromonas sp. cells. Mar. Pollut. Bull., 57, 877-882.

Mimura, H., Sato, R., Sasaki, Y., Furuyama, Y., Taniike, A., Yoshida, K., and Kitamura, A. (2008b) Accelerator analysis of tributyltin adsorbed onto the surface of a tributyltin resistant marine Pseudoalteromonas sp. cell. Int. J. Mol. Sci., 9, 1989-2002.

Murai, R., Takahashi, S., Tanabe, S., and Takeuchi, I. (2005) Status of butyltin pollution along the coasts of western Japan in 2001, 11 years after partial restrictions on the usage of tributyltin. Mar. Pollut. Bull., 51, 940-949.

Negri, A. P., Hales, L. T., Battershill, C., Wolff, C., and Webster, N. S. (2004) TBT contamination identified in Antarctic marine sediments. Mar. Pollut. Bull., 48, 11421144.

Nováková, Z., Bobálová, J., Vidová, M., Hapala, I., and Smigán, P. (2009) Tributyltin-resistant Methanothermobacter thermautotrophicus mutant with mutational substitutions in the A1AO-ATP synthase. FEMS Microbiol. Lett., 298, 255-259.

Oberdörster, E., Rittschof, D., and LeBlanc, G. A. (1998) Alteration of $\left[{ }^{14} \mathrm{C}\right]$-testosterone metabolism after chronic exposure of Daphnia magna to tributyltin. Arch. Environ. Contam. Toxicol., 34, 21-25.

Park, Y-. D., Baik, K. S., Seong, C. N., Bae, K. S., Kim, S., and Chun, J. (2006) Photobacterium ganghwense sp. nov., a halophilic bacterium isolated from sea water. Int. J. Syst. Evol. Microbiol., 56, 745-749.

Rivas, R., García-Fraile, P,, Mateos, P. F., Martínez-Molina, E., and Velázquez, E. (2006) Photobacterium halotolerans sp. nov., isolated from Lake Martel in Spain. Int. J. Syst. Evol. Microbiol., 56, 1067-1071.

Romano, I., Lama, L., Nicolaus, B., Poli, A., Gambacorta, A., and Giordano, A. (2006) Halomonas alkaliphila sp. nov., a novel halotolerant alkaliphilic bacterium isolated from a salt pool in Campania (Italy). J. Gen. Appl. Microbiol., 52, 339348.

Saeki, K., Nabeshima, A., Kunito, T., and Oshima, Y. (2007) The stability of butyltin compounds in a dredged heavilycontaminated sediment. Chemosphere, 68, 1114-1119.

Saitou, N., and Nei, M., 1987. The neighbor-joining method: a new method for reconstructing phylogenetic trees. Mol. Biol. Evol., 4, 406-425.

Smith, S. K., Sutton, D. C., Fuerst, J. A., and Reichelt, J. L. (1991) Evaluation of the genus Listonella and reassignment of Listonella damsela (Love et al.) MacDonell and Colwell to the genus Photobacterium as Photobacterium damsela comb. nov. with an emended description. Int. J. Syst. Bacteriol., 41, 529-534.

Sudaryanto, A., Takahashi, S., Monirith, I., Ismail, A., Muchtar, M., Zheng, J., Richardson, B. J., Subramanian, A., Prudente, M., Hue, N. D., and Tanabe, S. (2002) Asia-Pacific mussel watch: Monitoring of butyltin contamination in coastal waters of Asian developing countries. Environ. Toxicol. Chem., 21, 2119-2130

Suzuki, S., Fukagawa, T., and Takama, K. (1992) Occurrence of tributyltin-tolerant bacteria in tributyltin- or cadmiumcontaining seawater. Appl. Environ. Microbiol., 58, 34103412.

Thompson, F. L., Thompson, C. C., Naser, S., Hoste, B., Vandemeulebroecke, K., Munn, C., Bourne, D., and Swings, J. (2005) Photobacterium rosenbergii sp. nov. and Enterovibrio coralii sp. nov., vibrios associated with coral bleaching. Int. J. Syst. Evol. Microbiol., 55, 913-917.

Ueno, D., Inoue, S., Takahashi, S., Ikeda, K., Tanaka, H., Subramanian, A. N., Fillmann, G., Lam, P. K., Zheng, J., Muchtar, M., Prudente, M., Chung, K., and Tanabe, S. (2004) Global pollution monitoring of butyltin compounds using skipjack tuna as a bioindicator. Environ. Pollut., 127, $1-12$.

Wuertz, S., Miller, C. E., Pfister, R. M., and Cooney, J. J. (1991) Tributyltin-resistant bacteria from estuarine and freshwater sediments. Appl. Environ. Microbiol., 57, 27832789. 